\title{
Mobbinge Maruz Kalma Durumunun Belirlenmesi: Hemşireler Üzerine Bir Çalışma
}

\author{
Ilkay Sevinç TURAÇ, Bayram ŞAHIN*
}

Mobbinge Maruz Kalma Durumunun Belirlenmesi: Hemşireler Üzerine Bir Çalışma

Özet

Hemşirelerin mobbinge maruz kalma durumlarının belirlenmesi amacıyla Ankara'daki beş hastanede çalışan hemşireler üzerinde anket yapılmıştır. 953 anketten 755 tanesi geri dönmüş, veri analizinde 689 anket esas alınmıştır. Hemşirelerin mobbinge maruz kalma düzeylerini ölçmek için Leymann'ın geliştirdiği LIPT ölçeği kullanımıştır. Kasım 2012 - Mart 2013 arasında yapılan çalışma incelendiğinde; hemşirelerin en fazla iletişim boyutundan mobbinge maruz kaldıkları, \%68,5'inin yöneticileri tarafından mobbinge maruz bırakıldıkları tespit edilmiştir. Ayrıca, hemşirelerin mobbinge maruz kalma durumlarının çalışıkları bölümlere, toplam çalışma süresine, yönetsel pozisyonlarına göre anlamlı bir farklılık $(p<0,05)$ gösterdiği bulunurken, çalıştıkları hastane türlerine, eğitim düzeylerine ve kurumda çalışma şekli değişkenlerine göre anlamlı farka rastlanmadığı $(p>0,05)$ bulunmuştur. Çalışma sonuçları hemşirelerin mobbinge maruz kaldıkları alanların belirlenmesinde, bu yönde gerekli yönetsel önlemlerin alınmasında önemli ipuçları sunacaktır.

Anahtar Kelimeler: Mobbing, hemşireler, hastaneler
Determining the State of Being Subject to Mobbing: A Study on Nurses

Abstract

It was conducted to determine the status of nurses' exposure to mobbing situations. It was conducted on the nurses who work five hospitals in Ankara. Out of the 953 questionnaires which was distributed, 755 were returned. However the data analysis was based on total of 689 surveys. In order to measure the levels of nurses' exposure to mobbing LIPT developed by Leymann was used. It conducted between November 2012 March 2013 indicate that nurses are mostly exposed to mobbing situations on the communication dimension. The findings further reveal that $68.5 \%$ of the nurses are exposed to mobbing generated by their managers. Moreover, while the state of nurses subjected to mobbing shows significant differences regarding working departments, total working hours and whether they are in a management position ( $p<0.05$ ),no significant difference is observed considering the hospital type they are working with, their education level and their working way $(p>0.05)$. These findings will provide important clues in determining the areas in which the nurses are exposed to mobbing and the measures that should be taken in terms of administration.

Key Words: Mobbing, Nurses, Hospitals

\section{Giriş}

Örgütlerde insan ilişkilerinin önemi gün geçtikçe artmaktadır. Bilgi teknolojileriyle birlikte sürekli bir gelişimin ve değişimin yaşanması örgütleri de etkilemektedir. Örgütler sürdürülebilirliklerini sağlamak ve verimliliklerini artırabilmek için insan ilişkilerine ve kurum içi iletişime önem vermeli-

* Ilkay Sevinç TURAÇ, Arş. Gör., Hacettepe Üniversitesi, İktisadi ve İdari Bilimler Fakültesi, Sağlık İdaresi Bölümü, ilkaysevinc.turac@hacettepe.edu.tr; Bayram ŞAHIN, Prof. Dr., Hacettepe Üniversitesi, iktisadi ve İdari Bilimler Fakültesi, Sağlık İdaresi Bölümü, baysahin@hacettepe.edu.tr 
dirler. Çalışanların işyeri ortamında mutlu ve huzurlu bir şekilde çalışması verimliliği arttıran faktörlerden birisidir. İ̧̧ kazalarında artış olması, çok sık izin alınması, işe gelmeme gibi durumların iş yaşamında meydana gelmesi çalışanlar kadar kurum açısından da olumsuz bir durum sergilemektedir. Son zamanlarda özellikle çalışma ve yönetim psikolojisi alanında çalışma yapan birçok bilim adamı, işyerinde oluşan psikolojik şiddet, baskı nedeniyle ortaya çıktığını düşündükleri ve mobbing olarak adlandırdıkları bir olgu üzerinde tartışmaktadırlar (Tınaz, 2011).

Türkçede; işyerinde duygusal linç, işyerinde psikolojik terör, işyeri travması, işyerinde zorbalık, işyerinde psikolojik terör, işyerinde duygusal saldırı, yıldırma ve duygusal taciz gibi kavramlar mobbing yerine kullanılmaktadır. Saldırgan, tacizci, duygusal saldırgan, mobbing tacizcisi, zorba, mobbing uygulayan gibi kavramlar mobbingi uygulayan kişi/ler için kullanılırken; duygusal saldırıya uğrayan, mobbing kurbanı, mobbing mağduru, mağdur ve kurban kavramları da mobbinge maruz kalan kişi/ler için kullanılmaktadır (Çobanoğlu, 2005). Leymann (1990) yılında iş yaşamında mobbing kavramını, bir veya daha fazla kişi tarafından bir bireye karşı sistematik bir biçimde yapılan düşmanca ve etik olmayan davranış olarak tanımlamıştır. Mobbing davranışları sık sık (çoğunlukla her gün) ve uzun bir zaman periyodu içerisinde (en az altı ay) meydana gelmektedir (Leymann, 1990). Mobbing, çalışanlara astları ve üstleri tarafından yapılabildiği gibi eşit düzeydeki çalışanlar tarafından da sistematik bir şekilde yapılan tehdit, şiddet, aşağılama gibi her türlü kötü muameleyi içeren anlamlar taşımaktadır (Tınaz, 2011)."Mobbing, iş yerinde, bir veya nadiren birkaç çalışanın, bir veya daha fazla çalışan (nadiren dört kişiden fazla) tarafından, her gün veya birkaç ay süre ile sistematik olarak duygusal yönden zarar verici davranışlara maruz bırakılmasıdır." (Toker-Gökçe, 2008).

İ̧̧yerinde mobbing davranışlarına yol açan çeşitli etkenler vardır. Erkeklerle dolu bir ofiste yalnız bir kadın, kadınlarla dolu bir ofiste yalnız bir erkek, farklı inanç ve kültürler, farklı ırk ve kökenler, göz alııı güzellik gibi ifadeler mobbingin nedenleri arasında gösterilebilir. Çobanoğlu’na göre bu tür özelliklere sahip kişiler hak etmedikleri halde her an mobbing kurbanı olma potansiyeline sahiptirler (Çobanoğlu 2005). "Güç" işyeri ortamında maruz kalınan mobbing davranışları incelendiğinde dikkat çeken bir kavram olarak ortaya çıkmaktadır. "Güç" kavramının istenilen bir biçimde veya sağlıklı bir şekilde kullanılıp kullanılmamasından dolayı mobbing davranışları meydana gelmektedir (Yaman, 2009). Çalışanların ve organizasyonların sağlığı ve gelişimleri için istenmeyen her türlü kötü davranış olarak adlandırılan mobbing davranışlarının engellenmesi gerekir. İşyeri ortamında bu tür davranışların devam etmesi hem çalışanların hem de kurumun iyiye, ileriye gitmesinde engel teşkil edecektir. (Özler ve Mercan, 2009). İnsan ilişkilerine/kaynaklarına yönelik en büyük tehditlerden birisi olan mobbing insanı psikolojik ve fiziksel olarak tükenmişliğe sürükleyen, yıpratan, korkutan bir taciz şekli ve yaygın bir işyeri travmasıdır (Çobanoğlu, 2005). Mobbing hem bireyi hem de işyerini etkilemektedir. Mobbing mağdurunun sık sık izin alması, iş yerinden uzaklaşmaya çalışması, en son olarak işini terk etmesi örgütün etkililiğini de azaltmaktadır. Ayrıca işgücü devrinin fazla olması örgütlere pahalıya mal olmaktadır. Yeni bir kişinin işe alınması, bu kişinin işe uyum süreci gibi nedenler bunlardan bazılarıdır (Toker-Gökçe, 2008). Uykusuzluk, depresyon, sıkıntı, 
endişe, ağlama krizleri, unutkanlık, iştahsızlık, alınganlık, ani öfkelenme, içe kapanıklık gibi davranış ve tutum değişiklikleri mobbinge maruz kalan bireylerde meydana gelebilmektedir (Tınaz, 2011).

\subsection{Sağlık Sektöründe Mobbing}

Sağlık sektöründeki çalışma şartları ve ortamı düşünüldüğünde; bu sektörün emek yoğun bir sektör olması, kadın çalışanlarının fazla olması, uzun çalışma saatleri, iş stresinin fazla olması, hizmet verdikleri kişilerin hasta ve hasta yakınlarından oluşması gibi nedenlerden dolayı bu alanda diğer alanlara kıyasla mobbinge daha çok maruz kalınabilmektedir.

Literatür incelendiğinde, sağlık sektöründe mobbing davranışları; meslek grupları (hemşireler, doktorlar gibi) arasında, aynı meslek grupları (yönetici, alt-üst ilişkileri gibi) içerisinde sergilendiği gibi hasta ve hasta yakınları tarafından da uygulanabilmektedir. Aşağıda sağlık sektöründe mobbing ile ilgili yapılan bazı çalışmalara değinilmiştir.

Hemşirelerle ilgili Türkiye'de yapılan çalışmalar incelendiğinde; Yıldırım ve Yıldırım'ın (2007) yapmış olduğu çalışma; Türkiye'de sağılık alanında çalışan hemşirelerin yaşamış olduğu mobbing ve mobbingin hemşireler üzerindeki duygusal, sosyal ve psikolojik etkileri ve mobbingten kaçınmak için ne yapmaları gerektiği ile ilgili bir araştırmadır (Yıldırım ve Yıldıım, 2007). Benzer şekildeki bazı çalışmalara bakıldığında, Efe ve Ayaz tarafından (2010) yapılan çalışmada, hemşirelerin işyerinde mobbinge maruz kalıp kalmadığını ortaya çıkarmak amaçlanmıştır (Efe ve Ayaz, 2010). Yıldırım (2009) tarafından yapılan çalışmada ise Türkiye'de hemşirelerin yaşamış olduğu zorbalık ve bunun hemşirelerin çalışma yaşamına yansıyıp yansımadı̆̆ı incelenmiştir (Yıldııı, 2009). Yapılan bir diğer çalışmada Türkiye'de Sağlık Bakanlığına bağlı hastanelerde çalışan hemşirelere karşı yapılan cinsel tacizin nedenini, sıklığını ve sonuçlarını belirlemek amaçlanmıştır (Çelik ve Çelik, 2007). Bir diğer çalışmada işyerinde şiddet davranışlarına maruz kalan hemşirelerin şiddet algısına karar vermek için psikolojik olarak bir yöntem geliştirilmesi amaçlanmıştır (Yıldıım ve Yıldırım, 2008). Çelik ve diğerleri tarafından yapılan çalışmada Türkiye'de hemşirelere karşı yapılan sözel ve fiziksel istismarın sıklığının, nedenlerinin, hemşirelerin iş, aile, sosyal yaşamlarına önemli etkilerinin, baş etme yöntem ve faktörlerinin tanımlanması amaçlanmıştır (Çelik, Çelik, Ağırbaş, Uğurluoğlu, 2007). Erdemir ve diğerleri tarafından yapılan çalışmada ise Türkiye'nin doğu ve güneydoğu bölgesinde yer alan iki ayrı şehirde görev yapan hemşirelerin hastalar tarafından cinsel tacize uğrama durumlarını ve hemşirelerin cinsel taciz karşısında verdikleri tepkileri belirlemek amaçlanmıştır (Erdemir, Çıtak, Ulusoy, Geçkil, 2011). Bolışık ve diğerleri tarafından yapılan çalışmada ise, daha spesifik olarak pediatri kliniğinde çalışan hemşirelerin sözel istismara maruz kalma durumları incelenmiştir (Bolışı, Ak ve Karabudak, 2008).

Hemşirelerle ilgili yurtdışında yapılan çalışmalar incelendiğinde; İngiltere'deki bir çalışmada, hemşirelerin karşılaşabileceği işyeri şiddetinin sıklığını belirlemek, sağlık sonuçları ile zorbalık arasında bir ilişki olup olmadığı incelemek ve işyeri desteğinin zorbalık etkisini azaltıp azaltamayacă̆ını incelemek amaçlanmıştır (Quine, 2001). Camerino ve diğerleri tarafından Belçika, Almanya, Finlandiya, Fransa, İtalya, Hollanda, Polonya ve Slovakya dâhil olmak üzere sekiz AB ülkesinde hemşireler üzerine yapılan çalışmada bireysel, örgütsel ve psikososyal faktörler ve işyeri şiddeti türlerinin fre- 
kansları arasındaki ilişkileri ve algılanan sağlık ve örgütsel bağ|lık üzerindeki psikososyal faktörler ve şiddetin etkileşimini doğrudan değerlendirmek amaçlanmıştır (Camerino, Estryn-Behar, Conway, Der Heijden, Hasselhorn, 2008). Fornés ve diğerleri tarafından İspanya'da hemşireler üzerine yapılan çalışmada sosyodemografik değişkenlerle işyerinde psikolojik tacizin yaygın türlerinin incelenmesi amaçlanmıştır (Fornés, Cardoso, Castello, Gili, 2011). Samir ve diğerleri tarafından Mısır Kahire'de yapılan çalışmada kadın hastalıkları ve doğum hemşirelerine karşı işyerinde şiddet biçimlerini belirlemek ve şiddete karşı hemşirelerin tepki ve tutumlarının değerlendirilmesi amaçlanmıştır (Samir, Mohamed, Moustafa, Saif, 2012). Zampieron ve diğerleri tarafından iki İtalyan sağlık kuruluşunda yapılan çalışma, hemşirelere karşı algılanan saldırganlığı ölçmek ve saldırganların özellikleri ve saldırganlık türü arasında bir ilişki olduğu hipotezini doğrulamak amacıyla yapılmıştır (Zampieron, Galeazzo, Turra, Buja, 2010). Karsavuran (2011) tarafından yapılan çalışmada Sağlık Bakanlığı hastanelerinde yöneticilerin yıldırmaya maruz kalma düzeyleri ile tükenmişlik düzeyleri arasındaki ilişkinin ortaya konması amaçlanmıştır (Karsavuran, 2011). Dikmetaş ve diğerleri (2011) tarafından yapılan çalışmada ise asistan hekimlerin mobbing ve tükenmişlik düzeylerinin (duygusal tükenme, duyarsızlaşma ve kişisel başarı) cinsiyete, medeni duruma, çalışılan tıp bilimleri alanına, yaşa göre anlamlı farklılıklar gösterip göstermediğini belirlemek amaçlanmıştır (Dikmetaş, Top ve Ergin 2011). Şahin ve diğerlerinin (2012) yaptıkları çalışmada asistan doktorların mobbing davranışlarına maruz kalma düzeyleri ile karakteristik özellikleri arasında bir ilişki olup olmadığı incelenmiştir (Şahin, Çetin, Çimen, Yıldıran, 2012). Rutherford ve Rissel tarafından Yeni Güney Galler'da bir sağlık kuruluşunda yapılan çalışmada işyeri zorbalığının türü, boyutu ve sıkığını araştırmak amaçlanmıştır (Rutherford ve Rissel, 2004). Tekeş ve diğerleri tarafından yapılan çalışmada fiziksel ve psikolojik şiddetin meslek gruplarına göre dağılımını araştırmak amaçlanmıştır (Tekeş, Turhan, Keskin, Sur, Kızıltaş 2011). Şahin ve Dündar'ın (2011) yılında sağlık çalışanları ile ilgili yaptıkları çalışmada; sağlık çalışanlarının (hekim, hemşire, diğer) yıldırma ile karşılaşma sıklığını tespit etmek, en çok kimler tarafından yıldırmaya maruz bırakıldıklarını ve çalıştıkları hastanelerin mülkiyetine ve mesleklerine göre anlamlı bir farklılık olup olmadığını incelemek amaçlanmıştır (Şahin ve Dündar, 2011). Bilgel ve diğerleri tarafından sağlık, eğitim ve güvenlik sektörlerinde yapılan çalışmada beyaz önlüklü çalışanlar arasındaki işyeri zorbalığının rapor edilme sıklığını belirlemek, rapor edilen zorbalık ile bunun sağlığa etkisini ortaya çıkarmak ve zorbalığa maruz kalmış çalışanlar için iş desteği etkilerinin değerlendirilmesi amaçlanmıştır (Bilgel, Aytaç, Bayram, 2006). Çamcı ve Kutlu tarafından yapılan çalışmada sağlık alanında çalışan meslek gruplarının işyeri şiddeti ile karşılaşma oranı, şiddet çeşidi ve karşılaşılan şiddet çeşitlerini etkileyen kişisel ve mesleki özellikleri belirlemek amaçlanmıştır (Çamcı ve Kutlu, 2011).

Bu çalışma hemşirelerin yöneticileri tarafından mobbinge maruz kalma durumlarının belirlenmesi amacıyla yapılmıştır. Çalışmada hemşirelerin mobbing ile karşılaşma sıklıklarının belirlenmesinin yanı sıra mobbinge maruz kalma durumlarını etkileyen faktörlerin belirlenmesi amaçlanmıştır. Bu bağlamda hemşirelerin çalıştıkları hastane türüne, bölümlere, eğitim düzeylerine, toplam çalışma yılına, yönetsel pozisyonda olup olmamalarına, kurumda çalışma şekli değişkenlerine göre mobbinge maruz kalma durumları incelenecektir. 


\section{Yöntem}

Çalışmanın amacı Ankara ilinde hizmet sunmakta olan iki üniversite, iki özel ve bir kamu hastanesi olmak üzere beş hastanede çalışan hemşirelerin mobbinge maruz kalma durumlarını belirlemektir. Bu çalışma Kasım 2012 - Mart 2013 tarihleri arasında kesitsel olarak yapılmıştır. İzin alınan hastanelere dağıtılan toplam 953 anketten 755 tanesi geri dönmüştür, ancak veri analizinde 689 anket esas alınmıştır.

Araştırmada veri toplama yöntemi olarak anket kullanılacağı ve anket yöntemi kullanılarak yapılan çalışmalarda geri dönüş oranı genellikle birbirinden farklı olduğu için çalışmada hangi düzeyde geri dönüş olacağı öngörülememiş, dolayısıyla örneklem büyüklüğü hesaplanamamıştır. Bu bağlamda çalışma kapsamında yer alan hastanelerdeki hemşirelerden örneklem seçilmeyerek "en az 6 ay" çalışma süresi olan tüm hemşirelere ulaşılmaya çalışılmıştır. Çalışma kapsamındaki hastanelerde çalışan toplam hemşire sayısı 2287 'dir. Araştırmada ulaşılan hemşire sayısı 689'dur. Çalışmada gönüllülük esas alınmıştır.

Araştırmada veri toplama aracı olarak kullanılan anket iki bölümden oluşmaktadır. Birinci bölüm, araştırmaya katılan hemşirelerin sosyodemografik özelliklerini belirlemeye yönelik 12 sorudan oluşmaktadır. İkinci bölümde, hemşirelerin yöneticileri tarafından maruz kaldığı mobbing düzeyini belirlemek için LIPT (Leymann Inventory of Psychological Terrorization) Ölçeği kullanılmıştır. LIPT'te bulunan ifadelerden sadece herhangi birinde mobbinge maruz kalma durumunun saptanması bile katılımcının mobbing mağduru olarak kabul edilmesini sağlamaktadır. Ölçek; iletişim kurma olanağını hedef almaya yönelik davranışlar, sosyal hayatı hedef almaya yönelik davranışlar, itibarı ve saygınlığı hedef almaya yönelik davranışlar, mesleki durumu hedef almaya yönelik davranışlar ve fiziksel sağlığı hedef almaya yönelik davranışlar olmak üzere 5 boyuttan oluşmaktadır. İfadeleri ölçmek için sıklık derecesi olarak beş ölçüt belirlenmiş ve bu ölçütler; "evet, her gün”, "evet, haftada en az bir kere", "evet, ayda birkaç kez", "evet, yılda birkaç kez" ve "hayır, hiçbir zaman” biçiminde ankette yer almıştır. Literatürde mobbing davranışlarının, uzun bir süre içinde (en az altı ay) tekrarlanan bir şekilde gerçekleştiği ifade edilmektedir. Bu doğrultuda; araştırmaya katılanlardan ankette yer alan mobbing davranışlarına "6 ay süreklilik gösterecek şekilde" ne sıklıkta maruz kaldıklarını belirtmeleri istenmiştir.

Bu araştırmada kullanılan LIPT ölçeğinin Türkçe'ye çevirisi Önertoy (2003) tarafından yapılmış ve "Mobbing: İşyerinde Duygusal Taciz" adlı kitapta yayımlanmıştır. Ancak, kitaptaki ankette "Cinsel imalar" şeklinde yer alan ifade bu çalışmada kullanılan ankette; "Cinsel imalar yapılır"; "Fiziksel zarar" ifadesi "Sağlığınız için ciddi sonuçlara neden olabilecek fiziksel saldırılar yapılır" ve "Doğrudan cinsel taciz" ifadesi ise "Cinsel saldırılar yapıı (taciz vb)." şeklinde değiştirilmiştir.

\subsection{Araştırmanın Sınırlılıkları}

Araştırma sadece Ankara il merkezinde bulunan 5 hastanede yapılmıştır. Bu nedenle araştırma bulguları sadece bu hastanelerde çalışan hemşireleri yansıtmaktadır. Araştırmada ankete cevap veren hemşirelerle cevap vermeyenler arasında fark olup olmadığı kontrol edilememiştir. 
Illkay Sevinç TURAÇ | Bayram ŞAHiN

\subsection{Verilerin Analizi}

Araştırmadan elde edilen verilerin analizinde SPSS 20.0 istatistik programı kullanılmıştır. Araştırmaya katılan hemşirelerin sosyo-demografik özelliklerini incelemek için tanımlayıcı istatistiklerden ve mobbinge maruz kalma durumlarını etkileyen faktörleri belirlemek için $\chi^{2}$ testinden yararlanılmıştır.

\section{Bulgular}

Tablo 1. Mobbing Ölçeğinin (LIPT) Güvenilirlik Düzeyine Illişkin Bulgular

LIPT Ölçeği Boyutları Madde Sayısı Cronbach Alpha

İletişim Kurma Olanağını Hedef Almaya Yönelik Mobbing 11

0,91

Davranışları Boyutu

Sosyal Hayatı Hedef Almaya Yönelik Mobbing Davranışları

5

0,80

Boyutu

İtibarı ve Saygınlığı Hedef Almaya Yönelik Mobbing

15

0,91

Davranışları Boyutu

Mesleki Durumu Hedef Almaya Yönelik Mobbing Davranışları

9

0,89

Boyutu

Fiziksel Sağlığı Hedef Almaya Yönelik Mobbing Davranışları

5

0,76

Boyutu

Genel Güvenilirlik Düzeyi

45

0,96

Çalışmada kullanılan LIPT ölçeğinin güvenilirlik düzeyi incelendiğinde; ölçeğin genel güvenilirlik değerinin $\alpha=0,96$ olduğu görülmektedir. Alfa katsayısı 0,80 ile 1,00 arasında olduğunda geliştirilen testin/ölçeğin yüksek güvenilirliğe sahip olduğu bilinmektedir (Alpar, 2012).

Tablo 2. Araştırma Kapsamındaki Hemşirelerin Kişisel ve Mesleki Özellikleri

Değişkenler

Sayı

$\%$

\section{Cinsiyet}

Kadın

657

95,4

Erkek

32

4,6

Yaş

$=<30$

266

38,6

$>30$

313

45,4

Belirtilmemiş

110

16,0

92 
Medeni Durum

Evli

412

59,8

Bekâr

264

38,3

Diğer

12

1,7

Belirtilmemiş

1

,1

Eğitim Durumu

Lise

85

12,3

Ön Lisans

92

13,4

Lisans

474

68,8

Yüksek Lisans \& Doktora

34

4,9

Belirtilmemiş

4

,6

Hastane Türü

Devlet Hastanesi

152

22,1

Üniversite hastanesi

371

53,8

Özel Hastane

166

24,1

Toplam

689 100,0

Tablo 2 araştırma kapsamındaki hemşirelerin sosyo-demografik özellikleri hakkında genel bilgileri içermektedir. Elde edilen bulgulara göre; araştırmaya katılan hemşirelerin \%95,4'ünün kadınlardan oluştuğu, $\% 45,4^{\prime}$ ünün 30 yaş üstü çalışan olduğu, \%59,8'inin evli olduğu, \%68,8'inin lisans mezunu olduğu, \%53,8'inin üniversite hastanesinde görev yaptığı görülmektedir. 
Tablo 3. Hemşirelerin Yöneticileri Tarafından Olası Mobbing Davranışlarına Maruz Kalma Durumları

Olası Mobbing Davranışları

Mobbinge Mobbinge

maruz maruz

kalanlar kalmayanlar

\begin{tabular}{lrrrr} 
& Sayı & $\%$ & Sayı & $\%$ \\
\hline Üstünüz kendinizi gösterme olanaklarınızı kısıtlar. & 280 & 40,6 & 409 & 59,4 \\
Sözünüz sürekli kesilir. & 278 & 40,3 & 411 & 59,7 \\
Meslektaşlarınız veya birlikte çalıştığınız kişiler kendinizi gösterme & 280 & 40,6 & 409 & 59,4 \\
olanaklarınızı kısıtlar. & & &
\end{tabular}

Yüzünüze bağırılır, yüksek sesle azarlanırsınız.

$\begin{array}{llll}212 & 30,8 & 477 & 69,2\end{array}$

Yaptığınız iş sürekli eleştirilir.

$296 \quad 43,0 \quad 393 \quad 57,0$

Özel yaşamınız sürekli eleştirilir.

$113 \quad 16,4 \quad 576 \quad 83,6$

Telefonla rahatsız edilirsiniz.

$\begin{array}{llll}129 & 18,7 & 560 & 81,3\end{array}$

Sözlü tehditler alırsınız.

$92 \quad 13,4 \quad 597 \quad 86,6$

Yazılı tehditler alırsınız.

$\begin{array}{llll}35 & 5,1 & 654 & 94,9\end{array}$

Jestler ve bakışlarla iletişim reddedilir.

$243 \quad 35,3 \quad 446 \quad 64,7$

Imalar yoluyla iletişim reddedilir.

İletişim Kurma Olanağını Hedef Almaya Yönelik Mobbing

$\begin{array}{llll}226 & 32,8 & 463 & 67,2\end{array}$

Davranışları Boyutu

Çevrenizdeki insanlar sizinle konuşmazlar.

$\begin{array}{llll}439 & 63,7 & 250 & 36,3\end{array}$

Kimseyle konuşmazsınız, başkalarına ulaşmanız engellenir.

Size diğerlerinden ayrı bir iş yeri verilir.

$91 \quad 13,2 \quad 598 \quad 86,8$

$82 \quad 11,9 \quad 607 \quad 88,1$

$\begin{array}{llll}58 & 8,4 & 631 & 91,6\end{array}$

Meslektaşlarınızın sizinle konuşması yasaklanır.

$334,8 \quad 656 \quad 95,2$

Sanki orada değilmişsiniz gibi davranılır.

Sosyal Hayatı Hedef Almaya Yönelik Mobbing Davranışları

Boyutu

Insanlar arkanızdan kötü konuşur.

$111 \quad 16,1 \quad 578 \quad 83,9$

$\begin{array}{llll}182 & 26,4 & 507 & 73,6\end{array}$

Asılsız söylentiler ortada dolaşır.

$149 \quad 21,6 \quad 538 \quad 78,1$

$164 \quad 23,8 \quad 525 \quad 76,2$

Gülünç durumlara düşürülürsünüz.

$\begin{array}{llll}67 & 9,7 & 622 & 90,3\end{array}$

Akıl hastasıymışsınız gibi davranılır.

$\begin{array}{llll}36 & 5,2 & 653 & 94,8\end{array}$

Psikolojik değerlendirme/inceleme geçirmeniz için size baskı yapılır.

Bir özrünüzle alay edilir.

$48 \quad 7,0 \quad 641 \quad 93,0$

Sizi gülünç duruma düşürmek için yürüyüşünüz, jestleriniz veya sesiniz taklit edilir.

$\begin{array}{llll}46 & 6,7 & 643 & 93,3\end{array}$

$\begin{array}{llll}68 & 9,9 & 621 & 90,1\end{array}$

Dini veya siyasi görüşünüzle alay edilir.

$\begin{array}{llll}50 & 7,3 & 639 & 92,7\end{array}$

Özel yaşamınızla alay edilir.

$49 \quad 7,1 \quad 640 \quad 92,9$ 
Milliyetinizle alay edilir.

Özgüveninizi olumsuz etkileyen bir iş yapmaya zorlanırsınız.

Çabalarınız yanlış ve küçültücü şekilde yargılanır.

Kararlarınız sürekli sorgulanır.

Müstehcen ya da alçaltııı isimlerle anılır/hakaret edilirsiniz.

Cinsel imalar yapılır.

İtibarı ve Saygınlığı Hedef Almaya Yönelik Mobbing Davranışları

Sizin için hiçbir özel görev yoktur.

Size verilen işler geri alınır, faaliyetlerden mahrum edilirsiniz.

Sürdürmeniz için anlamsız işler verilir.

Sahip olduğunuzdan daha az yetenek gerektiren işler verilir.

İşiniz sürekli değiştirilir.

Özgüveninizi etkileyecek işler verilir.

İtibarınızı düşürecek şekilde, niteliklerinizin dışındaki işler size verilir.

Kasıtlı olarak büyük paralar harcamaya zorlanırsınız.

İş yerinize veya evinize zarar vermek için kazalara sebep olunur.

Mesleki Durumu Hedef Almaya Yönelik Mobbing Davranışları

Boyutu

Tehlikeli işler size verilir.

Fiziksel şiddet tehditleri yapılır.

Gözünüzü korkutmak için hafif şiddet uygulanır.

Sağlığınız için ciddi sonuçlara neden olabilecek fiziksel saldırılar yapılır.

Cinsel saldırılar yapılır. (taciz vb.)

Fiziksel Sağlığı Hedef Almaya Yönelik Mobbing Davranışları

Boyutu

Genel Mobbing Davranışları Boyutu

\begin{tabular}{|c|c|c|c|}
\hline 29 & 4,2 & 660 & 95,8 \\
\hline 111 & 16,1 & 578 & 83,9 \\
\hline 123 & 17,9 & 566 & 82,1 \\
\hline 95 & 28,3 & 494 & 71,7 \\
\hline 30 & 4,4 & 659 & 95,6 \\
\hline 32 & 4,6 & 657 & 95,4 \\
\hline 304 & 44,1 & 385 & 55,9 \\
\hline 103 & 14,9 & 586 & 85,1 \\
\hline 57 & 8,3 & 632 & 91,7 \\
\hline 101 & 14,7 & 588 & 85,3 \\
\hline 115 & 16,7 & 574 & 83,3 \\
\hline 77 & 11,2 & 612 & 88,8 \\
\hline 85 & 12,3 & 604 & 87,7 \\
\hline 65 & 9,4 & 624 & 90,6 \\
\hline 28 & 4,1 & 661 & 95,9 \\
\hline 23 & 3,3 & 666 & 96,7 \\
\hline 203 & 29,5 & 486 & 70,5 \\
\hline 73 & 10,6 & 616 & 89,4 \\
\hline 31 & 4,5 & 658 & 95,5 \\
\hline 38 & 5,5 & 651 & 94,5 \\
\hline 28 & 4,1 & 661 & 95,9 \\
\hline 20 & 2,9 & 669 & 97,1 \\
\hline 100 & 14,5 & 589 & 85,5 \\
\hline 72 & 68,5 & 217 & 31,5 \\
\hline
\end{tabular}

Tablo 3, hemşirelerin 5 boyut altında yer alan 45 olası mobbing davranışına maruz kalma durumlarına ilişkin bilgileri göstermektedir. Orijinal ölçekte mobbing durumlarına ilişkin bilgiler (1) evet, her gün, (2) evet, haftada en az bir kere, (3) evet, ayda birkaç kez, (4) evet, yılda birkaç kez, (5) hayır, hiçbir zaman şeklinde bir ölçeğe dayalı olarak yapılmıştır. Fakat bu çalışmada, "evet, her gün", "evet, haftada en az bir kere", "evet, ayda birkaç kez" ile "evet, yılda birkaç kez" seçenekleri birleştirilerek "mobbinge maruz kalanlar" grubu oluşturulmuş; "hayır, hiçbir zaman" ifadesi ise "mobbinge maruz kalmayanlar" olarak belirlenip iki grup olarak tabloda gösterilmiştir. 
Illkay Sevinç TURAÇ | Bayram ŞAHIN

Genel mobbing boyutu incelendiğinde; araştırma kapsamında yer alan hemşirelerin \%68,5'inin son 6 ay içerisinde olası mobbing davranışlarından en az birine maruz kaldığı belirlenmiştir. Beş mobbing boyutu açısından bakıldığında ise; hemşirelerin \%63,7 ile en fazla "iletişim Kurma Olanağını Hedef Almaya Yönelik Mobbing Davranışları”na maruz kaldığı tespit edilmiştir. Sırasıyla hemşirelerin \%44,1'inin “itibarı ve Saygınlığı Hedef Almaya Yönelik Mobbing Davranışları Boyutu”na, \%29,5'i “Mesleki Durumu Hedef Almaya Yönelik Mobbing Davranışları Boyutu”na, \%26,4'ünün "Sosyal Hayatı Hedef Almaya Yönelik Mobbing Davranışları Boyutu"na ve \%14,5'inin “Fiziksel Sağlığı Hedef Almaya Yönelik Mobbing Davranışları Boyutu"na maruz kaldıkları ortaya çıkmıştır.

Hemşirelerin “iletişim Kurma Olanağını Hedef Almaya Yönelik Mobbing Davranışları” içerisinde en fazla \%43'lük oran ile "yaptığınız iş sürekli eleştirilir", en az \%5,1'lik oran ile "yazılı tehditler alırsınız" ifadelerine katılıkları; "Sosyal Hayatı Hedef Almaya Yönelik Mobbing Davranışları Boyutu" incelendiğinde, hemşirelerin en fazla \%16,1'lik oran ile "sanki orada değilmişsiniz gibi davranıIır", en az \%4,8'lik oran ile "meslektaşlarınızın sizinle konuşması yasaklanır" ifadelerine katıldıkları görülmüştür. "itibarı ve Saygınlığı Hedef Almaya Yönelik Mobbing Davranışları Boyutu"na bakıldığında ise hemşirelerin en fazla \%28,3'lük oran ile "kararlarınız sürekli sorgulanır", en az \%4,2'lik oran ile "milliyetinizle alay edilir" ifadelerine katıldıkları belirlenmiştir. "Mesleki Durumu Hedef Almaya Yönelik Mobbing Davranışları Boyutu" incelendiğinde, hemşirelerin en fazla \%16,7'lik oran ile "sahip olduğunuzdan daha az yetenek gerektiren işler size verilir", en az \%3,3”lük oran ile "iş yerinize veya evinize zarar vermek için kazalara sebep olunur" ifadelerine katıldıkları belirlenmiştir. Son olarak "Fiziksel Sağlığı Hedef Almaya Yönelik Mobbing Davranışları Boyutu” incelendiğinde ise hemşirelerin en fazla \%10,6'।ık oran ile "tehlikeli işler size verilir"; en az \%2,9'luk oran ile "cinsel saldırılar yapılır (taciz vb.)" ifadelerine katıldıkları belirlenmiştir.

Genel olarak hemşirelerin en fazla maruz kaldığı mobbing davranışları incelendiğinde ise; hemşirelerin \%43'ünün "yaptığını iş sürekli eleştirilir", \%40,6'sının "kendinizi gösterme olanaklarınız kısıtlanır", \%40,3'ünün "sözünüz sürekli kesilir", \%35,3'ünün "jestler ve bakışlarla iletişim reddedilir", \%32,8'inin "imalar yoluyla iletişim reddedilir" ve \%30,8'inin "yüzünüze bağırılır, yüksek sesle azarlanırsınız" ifadelerine katıldıkları bulunmuştur.

Bunların yanı sıra genel olarak en az maruz kalınan mobbing davranışlarına bakıldığında; "cinsel saldırılar yapılır (taciz vb.)" \%2,9, "iş yerinize veya evinize zarar vermek için kazalara neden olunur" \%3,3, "sağlığınız için ciddi sonuçlara neden olabilecek fiziksel saldırılar yapılır" \%4,1 ve "kasıtlı olarak büyük paralar harcamaya zorlanırsını" \%4,1 olarak bulunmuştur. 
Tablo 4. Hemşirelerin Yöneticileri Tarafından Mobbing İle Karşılaşma Durumlarının Çalıştıkları

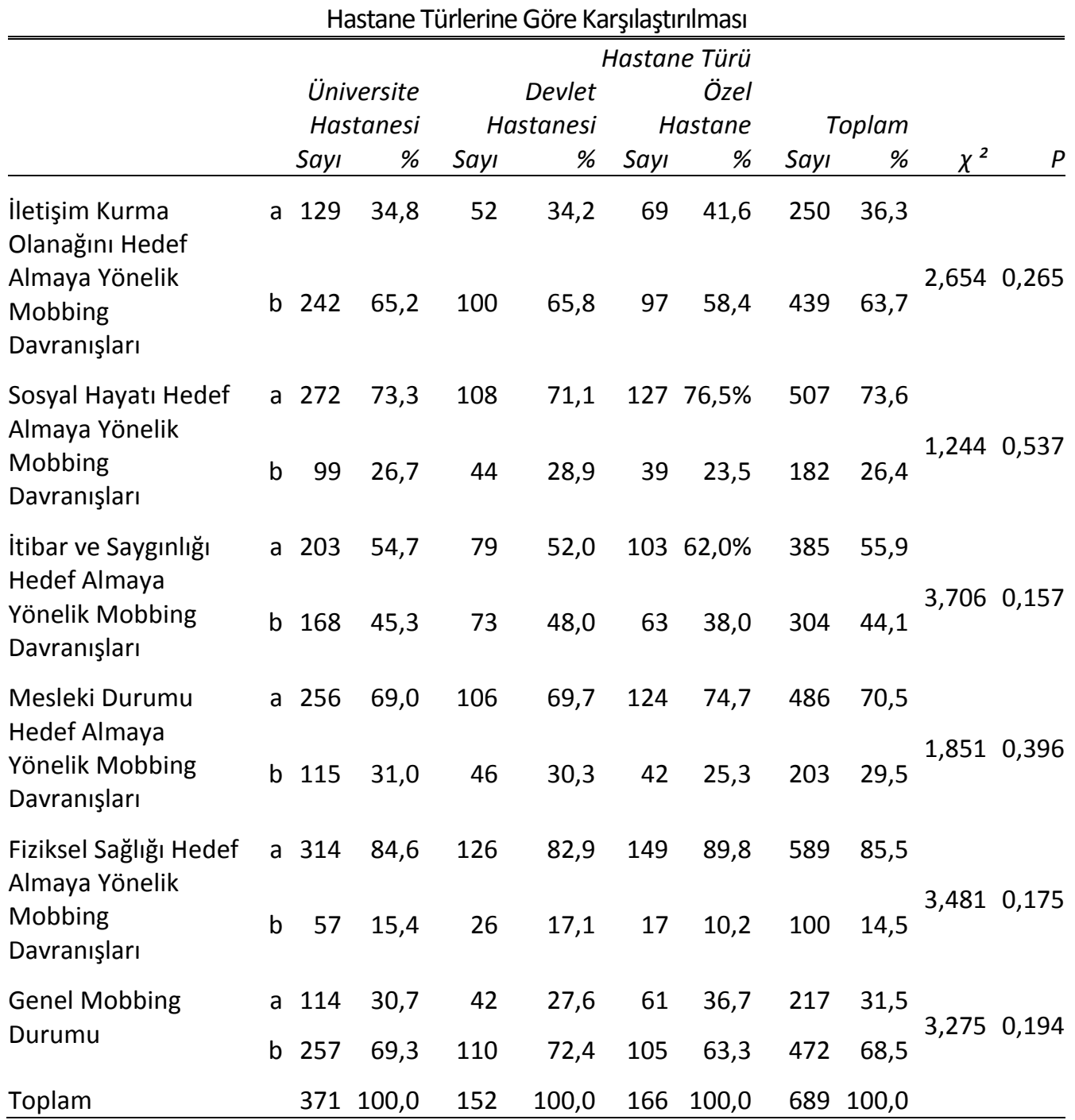

a: Mobbinge maruz kalmayanlar

b: Mobbinge maruz kalanlar

Tabloda, araştırma kapsamında yer alan hemşirelerin mobbinge maruz kalma durumları çalıştıkları hastanelere göre incelenmiştir.

Bulgulara göre, hemşirelerin yöneticileri tarafından mobbinge maruz kalma durumları çalıştıkları hastane türlerine göre 5 boyut açısından değerlendirildiğinde istatistiksel olarak anlamlı bir farklıı̆̆a $(p>0,05)$ rastlanmamıştır. 
Illkay Sevinç TURAÇ | Bayram ŞAHIN

Tablo 5. Hemşirelerin Yöneticileri Tarafından Mobbing Ille Karşılaşma Durumlarının Eğitim Düzeylerine Göre Karşılaştırılması

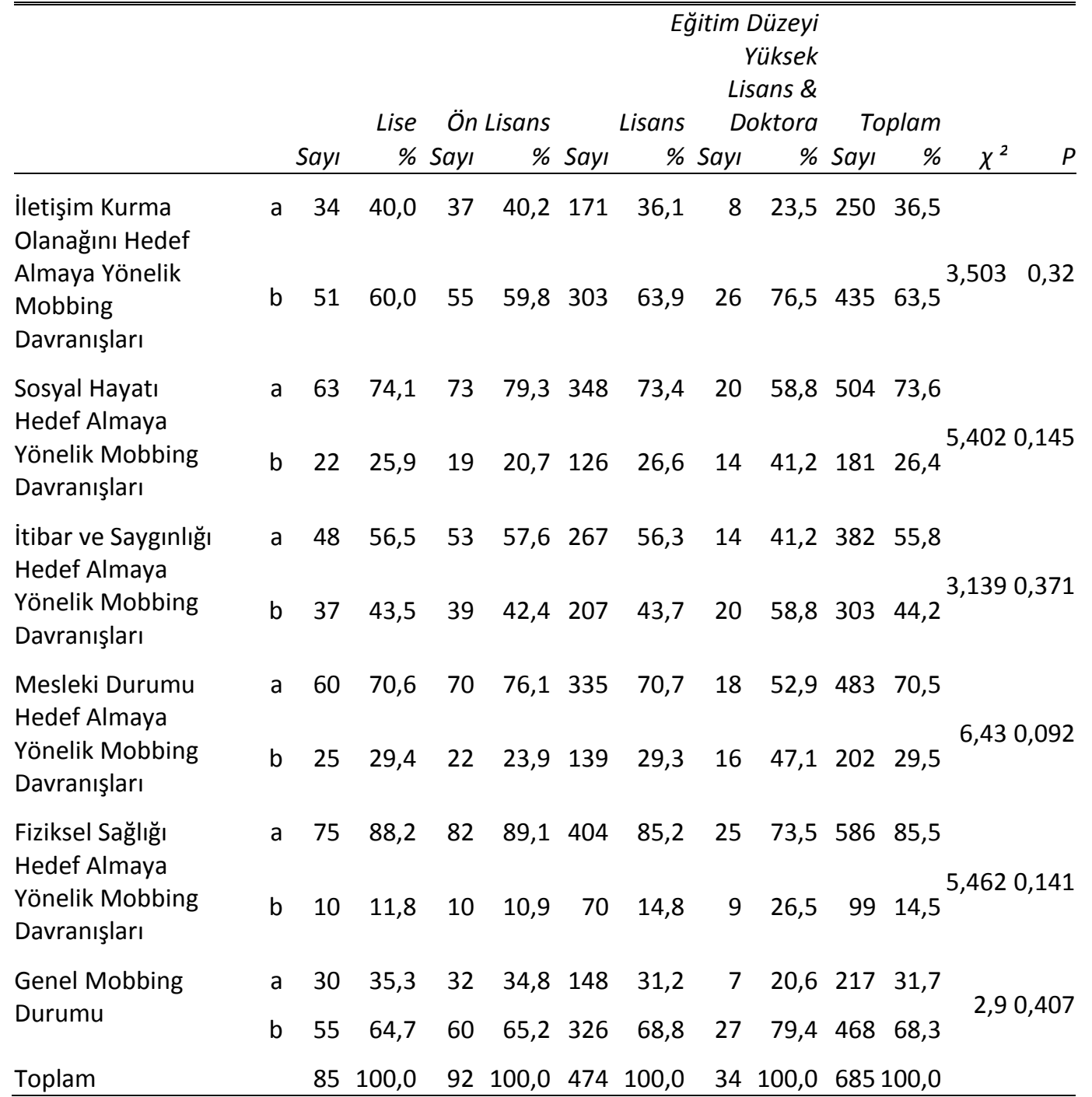

a: Mobbinge maruz kalmayanlar

b: Mobbinge maruz kalanlar

Tabloda, araştırma kapsamında yer alan hemşirelerin mobbinge maruz kalma durumları eğitim düzeylerine göre incelenmiştir. Tabloya bakıldığında, hemşirelerin yöneticileri tarafından 5 boyut altında toplanan mobbing davranışlarına maruz kalma durumlarının eğitim düzeylerine göre istatistiksel olarak anlamlı bir fark göstermediği ( $p>0.05)$ tespit edilmiştir. 
Hemşirelerin yöneticileri tarafından mobbinge maruz kalma durumları incelendiğinde, istatistiksel olarak anlamlı bir fark olmamasına rağmen, eğitim düzeylerine göre en fazla mobbinge maruz kalanların yüksek lisans/doktora eğitimi almış hemşireler olduğu tespit edilmiştir.

Tablo 6. Hemşirelerin Yöneticileri Tarafından Mobbing ile Karşılaşma Durumlarının Çalıştıkları Bölümlere Göre Karşılaştırılması

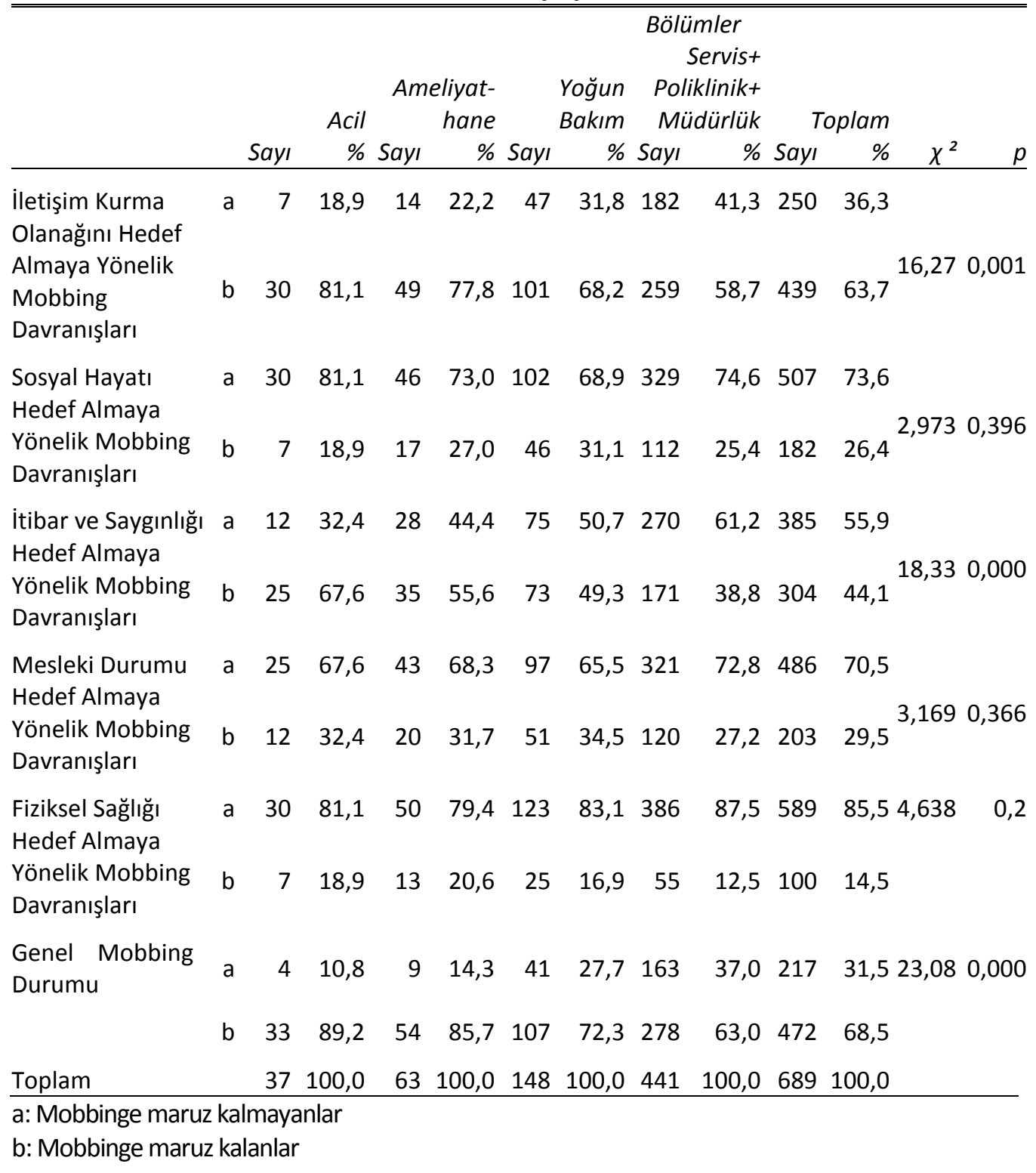


Tabloda, araştırma kapsamındaki hemşirelerin görev yaptıkları bölümlere göre yöneticileri tarafından mobbing davranışlarına maruz kalma durumları incelenmiştir.

Yöneticileri tarafından hemşirelerin; "genel mobbing durumu" $\left(\chi^{2}=23,08 ; p<0,05\right)$ ile "iletişim kurma olanağını hedef almaya yönelik davranışlara" $\left(\chi^{2}=16,27 ; p<0,05\right)$ ve "itibarı ve saygınlığı hedef almaya yönelik davranışlara" ( $\left.\chi^{2}=18,33 ; p<0,05\right)$ maruz kalma durumları ile çalıştıkları bölümler arasında istatistiksel olarak anlamlı bir ilişki olduğu bulunmuştur.

Yöneticileri tarafından mobbinge maruz kalan hemşireler arasında "iletişim kurma olanağını hedef almaya yönelik davranışlara" maruz kalma oranı genel \%63,7 olmasına karşın, çalıştıkları bölümler açısından bir değerlendirme yapıldığında; bu boyuttaki davranışlara en çok \%81,1 ile acil bölümünde çalışanların maruz kaldıkları, ikinci sırada \%77,8 ile ameliyathane çalışanlarının yer aldıkları, bunları \%68,2 ile yoğun bakım çalışanlarının ve \%58,7 ile servis/poliklinik/müdürlük çalışanlarının takip ettiği görülmüştür.

"İtibarı ve saygınlığı hedef almaya yönelik davranışlarda" yöneticileri tarafından mobbinge maruz kalan hemşirelerin oranı genel \%44,1 olmasına karşın, çalıştıkları bölümler açısından bir değerlendirme yapıldığında, bu boyuttaki davranışlara en çok \%67,6 ile acil servis çalışanlarının maruz kaldığı, daha sonra \%55,6 ile ameliyathane çalışanlarının geldiği, sırasıyla \%49,3 yoğun bakım ve \%38,8 ile servis/poliklinik/müdürlük çalışanlarının takip ettiği görülmüştür.

Kısaca hemşirelerin hastanede çalıştıkları bölümlere göre yöneticileri tarafından mobbinge maruz kalma durumları en çok acil servislerde meydana gelmekte ve bunu sırasıyla ameliyathane, yoğun bakım ve servis/poliklinik/müdürlük bölümleri izlemektedir.

Bulgulara göre, hemşirelerin yöneticileri tarafından mobbinge maruz kalma durumlarının "sosyal hayatı hedef almaya yönelik mobbing davranışları" ( $\left.\chi^{2}=2,973 ; p>0,05\right)$, "mesleki durumu hedef almaya yönelik mobbing davranışları" ( $\left.\chi^{2}=3,169 ; p>0,05\right)$, ve "fiziksel sağlığı hedef almaya yönelik mobbing davranışlarının" $\left(\chi^{2}=4,638 ; p>0,05\right)$ görev yaptıkları bölümlere göre değişmediğini göstermektedir.

Tablo 7. Hemşirelerin Yöneticileri Tarafından Mobbing ile Karşılaşma Durumlarının Toplam Çalışma Yıllarına Göre Karşılaştırıması

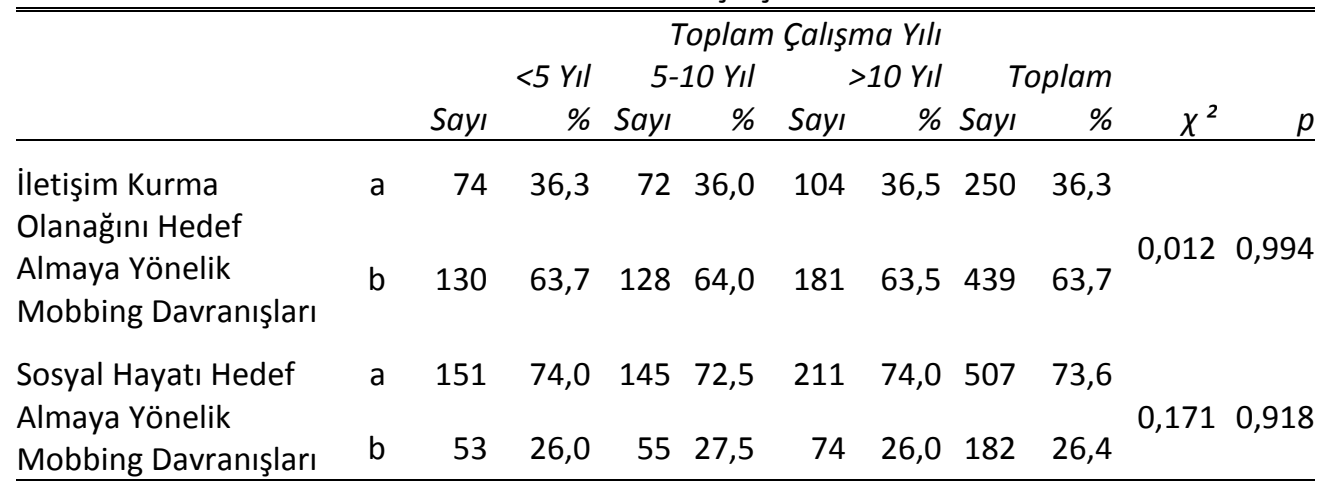




\begin{tabular}{|c|c|c|c|c|c|c|c|c|c|c|c|}
\hline İtibar ve Saygınlığı & a & 109 & 53,4 & 107 & 53,5 & 169 & 59,3 & 385 & 55,9 & \multirow{3}{*}{2,306} & \multirow{3}{*}{0,316} \\
\hline Hedef Almaya Yönelik & & & & & & & & & & & \\
\hline Mobbing Davranışları & b & 95 & 46,6 & 93 & 46,5 & 116 & 40,7 & 304 & 44,1 & & \\
\hline \multirow{3}{*}{$\begin{array}{l}\text { Mesleki Durumu } \\
\text { Hedef Almaya Yönelik } \\
\text { Mobbing Davranışları }\end{array}$} & a & 138 & 67,6 & 129 & 64,5 & 219 & 76,8 & 486 & 70,5 & \multirow{3}{*}{9,779} & \multirow{3}{*}{0,008} \\
\hline & & & & & & & & & & & \\
\hline & b & 66 & 32,4 & 71 & 35,5 & 66 & 23,2 & 203 & 29,5 & & \\
\hline \multirow{3}{*}{$\begin{array}{l}\text { Fiziksel Sağlığı Hedef } \\
\text { Almaya Yönelik } \\
\text { Mobbing Davranışları }\end{array}$} & a & 172 & 84,3 & 166 & 83,0 & 251 & 88,1 & 589 & 85,5 & \multirow{3}{*}{2,756} & \multirow{3}{*}{0,252} \\
\hline & & & & & & & & & & & \\
\hline & b & 32 & 15,7 & 34 & 17,0 & 34 & 11,9 & 100 & 14,5 & & \\
\hline \multirow{2}{*}{$\begin{array}{l}\text { Genel Mobbing } \\
\text { Durumu }\end{array}$} & a & 63 & 30,9 & 60 & 30,0 & 94 & 33,0 & 217 & 31,5 & \multirow{2}{*}{0,535} & \multirow{2}{*}{0,765} \\
\hline & $b$ & 141 & 69,1 & 140 & 70,0 & 191 & 67,0 & 472 & 68,5 & & \\
\hline Toplam & & 204 & 100,0 & 200 & 100,0 & 285 & 100,0 & 689 & 100,0 & & \\
\hline
\end{tabular}

a: Mobbinge maruz kalmayanlar

b: Mobbinge maruz kalanlar

Tabloda, araştırma kapsamında hemşirelerin görev yaptıkları kurumlarda çalışma yıllarına göre yöneticileri tarafından mobbing davranışlarına maruz kalma durumları incelenmiştir.

Yöneticileri tarafından hemşirelerin; "mesleki durumu hedef almaya yönelik mobbing davranışlarına" ( $\left.\chi^{2}=9,779 ; p<0,05\right)$ maruz kalma durumları ile toplam çalışma yılları arasında istatistiksel olarak anlamlı bir ilişki olduğu bulunmuştur.

Hemşirelerin "mesleki durumu hedef almaya yönelik mobbing davranışlarına" maruz kalma oranı genel \%29,5 iken, toplam çalışma yılları arasında bir değerlendirme yapıldığında; bu boyuttaki davranışlara en çok \%35,5 ile 5-10 yıl arasında çalışan hemşirelerin maruz kaldıkları, bunu sırasıyla $\% 32,4$ ile 5 yıldan daha az çalışanların ve \%23,2 ile 10 yıldan fazla süredir çalışanların izlediği görülmüştür.

Tablo 8. Hemşirelerin Yöneticileri Tarafından Mobbing İle Karşılaşma Durumlarının Yönetsel Pozisyon Durumlarına Göre Karşılaştırııması

\begin{tabular}{|c|c|c|c|c|c|c|c|c|c|}
\hline & & & Yön & tsel P & yonu & & & & \\
\hline & & & Olan & & ayan & & plam & & \\
\hline & & Sayı & $\%$ & Sayı & $\%$ & Sayı & $\%$ & $x^{2}$ & $p$ \\
\hline İletişim Kurma Olanağını & a & 44 & 37,6 & 206 & 36,0 & 250 & 36,3 & & \\
\hline Hedef Almaya Yönelik & & & & & & & & 0,107 & 0,744 \\
\hline Mobbing Davranışları & b & 73 & 62,4 & 366 & 64,0 & 439 & 63,7 & & \\
\hline Sosyal Hayatı Hedef & a & 91 & 77,8 & 416 & 72,7 & 507 & 73,6 & & \\
\hline Almaya Yönelik & & & & & & & & 1,275 & 0,259 \\
\hline Mobbing Davranışları & $b$ & 26 & 22,2 & 156 & 27,3 & 182 & 26,4 & & \\
\hline
\end{tabular}


Illkay Sevinç TURAÇ | Bayram ŞAHIN

\begin{tabular}{|c|c|c|c|c|c|c|c|c|c|}
\hline İtibar ve Saygınlığı & a & 76 & 65,0 & 309 & 54,0 & 385 & 55,9 & \multirow[b]{2}{*}{4,712} & \multirow[b]{2}{*}{0,03} \\
\hline $\begin{array}{l}\text { Hedef Almaya Yönelik } \\
\text { Mobbing Davranışları }\end{array}$ & b & 41 & 35,0 & 263 & 46,0 & 304 & 44,1 & & \\
\hline Mesleki Durumu Hedef & a & 92 & 78,6 & 394 & 68,9 & 486 & 70,5 & \multirow[b]{2}{*}{4,444} & \multirow[b]{2}{*}{0,035} \\
\hline $\begin{array}{l}\text { Almaya Yönelik } \\
\text { Mobbing Davranışları }\end{array}$ & b & 25 & 21,4 & 178 & 31,1 & 203 & 29,5 & & \\
\hline \multirow{2}{*}{$\begin{array}{l}\text { Fiziksel Sağlığı Hedef } \\
\text { Almaya Yönelik } \\
\text { Mobbing Davranışları }\end{array}$} & a & 100 & 85,5 & 489 & 85,5 & 589 & 85,5 & \multirow[b]{2}{*}{0} & \multirow[b]{2}{*}{0,996} \\
\hline & b & 17 & 14,5 & 83 & 14,5 & 100 & 14,5 & & \\
\hline \multirow{2}{*}{$\begin{array}{l}\text { Genel Mobbing } \\
\text { Durumu }\end{array}$} & a & 40 & 34,2 & 177 & 30,9 & 217 & 31,5 & \multirow{2}{*}{0,474} & \multirow{2}{*}{0,491} \\
\hline & b & 77 & 65,8 & 395 & 69,1 & 472 & 68,5 & & \\
\hline Toplam & & 117 & 00,0 & 572 & 100,0 & 689 & 100,0 & & \\
\hline
\end{tabular}

a: Mobbinge maruz kalmayanlar

b: Mobbinge maruz kalanlar

Tabloda, araştırma kapsamında hemşirelerin yönetsel pozisyon durumlarına göre yöneticileri tarafından mobbing davranışlarına maruz kalma durumları incelenmiştir.

Yöneticileri tarafından hemşirelerin; “itibarı ve saygınlığı hedef almaya yönelik davranışlara” ( $\chi$ $\left.{ }^{2}=4,712 ; p<0,05\right)$ ve "mesleki durumu hedef almaya yönelik davranışlara" $\left(\chi^{2}=4,444 ; p<0,05\right)$ maruz kalma durumları ile yönetsel pozisyonları arasında istatistiksel olarak anlamlı bir ilişki olduğu bulunmuştur.

Yöneticileri tarafından mobbinge maruz kalan hemşireler arasında "itibarı ve saygınlığı hedef almaya yönelik davranışlarda" mobbinge maruz kalan hemşirelerin oranı genel \%44,1 olmasına karşın, yönetsel pozisyon açısından değerlendirildiğinde, bu boyuttaki davranışlara en çok \%46,0 ile yönetsel pozisyona sahip olmayanların maruz kaldığı görülmüştür.

"Mesleki durumu hedef almaya yönelik davranışlara" maruz kalma oranı genelde \%29,5 iken, yönetsel pozisyon açısından değerlendirildiğinde, \%31,1 ile yönetsel pozisyona sahip olmayan hemşirelerin daha çok mobbinge maruz kaldığı görülmektedir. 
Tablo 9. Hemşirelerin Yöneticileri Tarafından Mobbing ile Karşılaşma Durumlarının Kurumda ÇaIışma Şekillerine Göre Karşılaştııılması

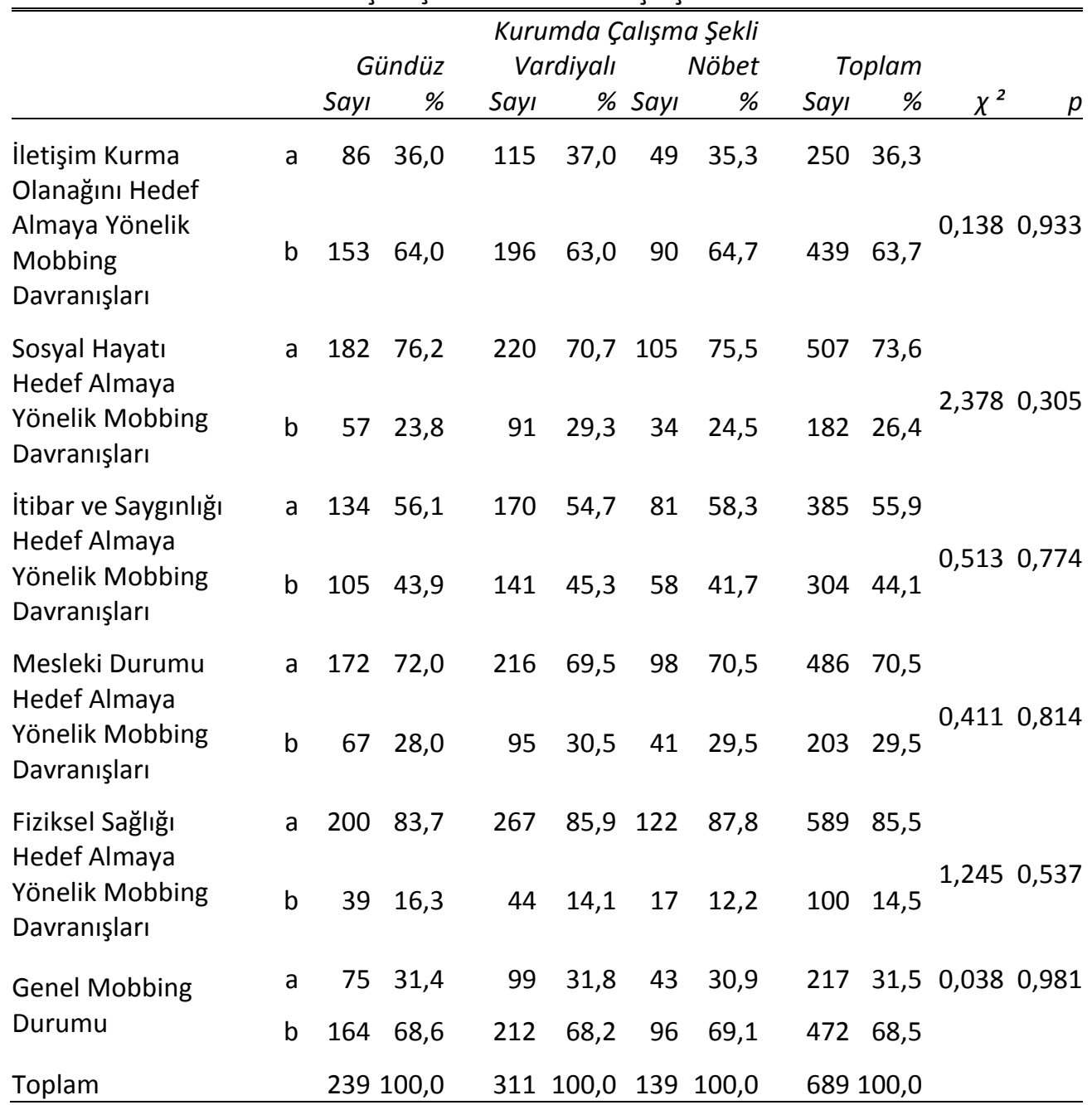

a: Mobbinge maruz kalmayanlar

b: Mobbinge maruz kalanlar

Tabloda, araştırma kapsamında yer alan hemşirelerin mobbinge maruz kalma durumları kurumda çalışma şekillerine göre incelenmiştir. Tabloya bakıldığında, hemşirelerin yöneticileri tarafından 5 boyut altında toplanan mobbinge maruz kalma durumlarının kurumda çalışma şekillerine göre istatistiksel olarak anlamlı bir fark göstermediği ( $p>0.05)$ tespit edilmiştir.

Genel mobbing boyutu incelendiğinde; araştırma kapsamında yer alan hemşirelerin $\% 68,5^{\prime}$ inin son 6 ay içerisinde olası mobbing davranışlarından en az birine maruz kaldığı belirlen- 
Illkay Sevinç TURAÇ | Bayram ŞAHIN

miştir. 5 mobbing boyutu açısından bakıldığında ise; hemşirelerin \%63,7 ile en fazla "iletişim Kurma Olanağını Hedef Almaya Yönelik Mobbing Davranışları”na maruz kaldığı tespit edilmiştir. Sırasıyla hemşirelerin \%44,1'inin “itibarı ve Saygınlığı Hedef Almaya Yönelik Mobbing Davranışları Boyutu"na, \%29,5'inin "Mesleki Durumu Hedef Almaya Yönelik Mobbing Davranışları Boyutu"na, \%26,4'ünün "Sosyal Hayatı Hedef Almaya Yönelik Mobbing Davranışları Boyutu"na ve \%14,5'inin “Fiziksel Sağlığı Hedef Almaya Yönelik Mobbing Davranışları Boyutu”na maruz kaldıkları ortaya çıkmıştır.

\section{Tartışma ve Sonuç}

Günümüzde çalışanlar eğitim, turizm, sağlık gibi birçok çalışma ortamında mobbing ile karşı karşıya kalmaktadır. Bunların içerisinde özellikle emek yoğun bir sektör olan sağlık sektöründe mobbing süreci çok yıpratıcı olabilmektedir. Literatür incelendiğinde sağlık çalışanlarının özellikle hemşirelerin mobbinge maruz kalma düzeylerini inceleyen birçok çalışma olduğu görülmektedir.

Şiddet sanayileşmiş dünyada birçok ülkede ciddi bir sorun olarak bilinmektedir. Yeni araştırmalar sağılı hizmeti verilen yerlerde şiddetin küresel bir fenomen olduğunu göstermektedir. Kültürler, çalışma ortamı, meslek grupları, sağlık hizmeti verilen yerlerde şiddet, gelişmekte olan ülkeler de dâhil olmak üzere tüm toplumlarda bir salgın gibi görülmektedir. Gelişmekte olan ve geçiş ülkelerindeki yeni araştırma sonuçlarında veriler, önceden mevcut olmayan veya çok az elde edilen bu konuyla ilgili veriler sağlık sektöründe çalışan personelin yarıdan fazlasının son bir yıl içerisinde fiziksel veya psikolojik şiddet olaylarından en az birine maruz kaldığını göstermektedir (ILO/ICN/WHO/PSI, 2002).

Ankara ilinde hizmet sunmakta olan beş hastanede çalışan hemşirelerin mobbinge maruz kalma durumlarının belirlenmesi amacıyla yapılan çalışmada, araştırmaya katılan hemşirelerin son 6 ay içerisinde 5 boyut altında sınıflandırılmış olası mobbing davranışlarından en az birine maruz kalma oranı \%68,5 olarak bulunmuştur. Benzer şekilde, Şahin ve Dündar'ın (2011) yılında sağlık çalışanları ile ilgili yaptıkları çalışmada, sağlık çalışanlarının \%70,4'ünün mobbing davranışlarından en az birine maruz kaldığı tespit edilmiştir (Şahin ve Dündar, 2011). Türkiye'deki benzer çalışmalara bakıldığında; Yıldırım ve Yıldıım'ın (2007) yapmış olduğu çalışmada; çalışmaya katılan hemşirelerin \%86,5'inin son bir yılda işyerinde mobbing davranışlarıyla karşılaştığı belirlenmiştir (Yıldırım ve Yıldırım, 2007). Yıldırım (2009) tarafından yapılan çalışmada; araştırmaya katılan hemşirelerin \%21'i son bir yılda mobbing davranışlarına maruz kalmıştır (Yıldırım, 2009). Bolışık ve diğerleri tarafından yapılan çalışmada, araştırmaya katılan 75 pediatri hemşiresinin 70'i $(\% 93,3)$ sözel istismar yaşadığını ifade etmiştir (Bolışık ve diğ., 2008). Dilman (2007) tarafından özel hastanelerde çalışan hemşireler üzerine yapılan araştırmada çalışmaya katılan hemşirelerin \%70'inin duygusal tacize maruz kaldığı belirlenmiştir. Çelik ve Çelik (2007) tarafından hemşireler üzerinde yapılan çalışmada ise katıımcıların \%37,1'inin cinsel tacize maruz kaldığı ortaya çıkmıştır (Çelik ve Çelik, 2007). Bilgel ve diğerleri tarafından sağık, eğitim ve güvenlik sektörlerinde yapılan çalışmada, çalışmaya katılanların \%55'inin son bir yılda bir veya daha fazla kez zorbalığa maruz kaldığı, zorbalığın ise çoğunlukla amir/yönetici gibi üst çalışanlar tarafından yapıldığı belirtilmiştir (Bilgel ve diğ., 2006). Çamcı ve Kutlu tarafından Kocaeli'nde sağılık çalışanları üzerine yapılan araştırmada, sağlık çalışanlarının 
\%72,6'sının sağlık sektöründe çalıştıkları süre boyunca herhangi bir şiddet türüne maruz kaldığı ve son 12 ay içerisinde de \%72,4'ünün şiddete uğradığı belirtilmiştir (Çamcı ve Kutlu, 2011). Çelik ve diğerleri tarafından hemşireler üzerine yapılan çalışmada hemşirelere karşı sözlü ve fiziksel istismar sıklığı sırasıyla \% 91,1 ve \%33 olarak bulunmuştur (Çelik vd., 2007). Erdemir ve diğerleri tarafından yapılan çalışmada ise araştırmaya katılan hemşirelerin \%71,7'sinin cinsel taciz kapsamında yer alan davranış/eylemler ile karşılaştıkları, cinsel tacize uğradıkları belirtilmiştir (Erdemir ve diğ., 2011). Kısa tarafından yapılan çalışmada hemşirelerin çoğunluğunun \%79,4'ünün son bir yıl içerisinde sözlü tacize maruz kaldığı belirlenmiştir (Kısa, 2008).

Dünya Sağılı Örgütü’nün 2002 yılında hazırlamış olduğu rapor şiddetin dünyanın her yerinde sunulan sağlık hizmet kalitesini düşürdüğünü ve sağlık personellerinin işe devam etme isteğini azalttığını ortaya çıkarmışır. Bunun yanı sıra şiddete maruz kalma riski farklıık göstermesine rağmen işyeri şiddetinin kadın ve erkek tüm sağlık çalışanlarını etkilediği belirtilmiştir. Tüm çalışmalarda, hemşire ve doktorların şiddete maruz kalma oranının çok yüksek olduğu rapor edilmiştir.

Portekiz'de büyük bir sağlık merkezinde yapılan çalışmada katılımcıların \%60'ı son bir yıl içerisinde şiddet olaylarından en az birine maruz kaldığını belirtmişlerdir. Bulgaristan'da katılımcıların \% 37'si, Lübnan'da ise \% 41'i psikolojik taciz türü olarak sözel şiddet olaylarını rapor etmişlerdir. Güney Afrika'da bu oran \% 61, Tayland'da ise \% 54 olarak belirtilmiştir (ILO/ICN/WHO/PSI, 2002). Benzer şekilde, Camerino ve diğerleri tarafından Belçika, Almanya, Finlandiya, Fransa, İtalya, Hollanda, Polonya ve Slovakya dahil olmak üzere sekiz $A B$ ülkesinde hemşireler üzerine yapılan çalışmada Polonya, Fransa ve Almanya'daki hemşirelerin şiddet türlerine maruz kalmada en yüksek frekansa sahip olduğu belirlenmiştir (Camerino ve diğ., 2008). Benzer çalışmalara bakıldığında, İngiltere'de Ulusal Sağlık Hizmeti (NHS)'ye sunulan raporda hemşirelerin \%44'ünün son 12 ay içerinde bir veya birden fazla zorbalık davranışına maruz kaldığı belirtilmiştir (Quine, 2001). Quine tarafından yapılan çalışma sonuçlarına bakıldığında, çalışmaya katılanların \%38'inin son bir yılda bir veya daha fazla zorbalığa maruz kaldığı ortaya çıkmıştır (Quine, 1999). Samir ve diğerleri tarafından Kahire'de yapılan çalışmada hemşirelerin çoğunluğunun \% 86,1'inin son altı ay içerisinde işyeri şiddetine maruz kaldığı belirtilmiştir (Samir ve diğ. 2012). Rutherford ve Rissel tarafından Yeni Güney Galler'da bir sağlık kuruluşunda yapılan çalışmada, katılımcıların \%50'sinin son on iki ay içerisinde zorbalık davranışlarına bir veya daha fazla kez maruz kaldıklarını belirtilmiştir (Rutherford ve Rissel, 2004). Zampieron ve diğerleri tarafından İtalya'da yapılan çalışmada ise çalışmaya katılan hemşirelerin \%49'unun son bir yıl içerisinde saldırganlığa maruz kaldığı belirtilirken, \%82'sinin ise sadece sözel taciz yaşadığı belirtilmiştir (Zampieron ve diğ., 2010).

Çalışmada hemşirelerin beş boyut altında toplanan mobbing davranışları arasında en çok \%63,7'lik bir oran ile "iletişim Kurma Olanağını Hedef Almaya Yönelik Mobbing Davranışları" ile karşılaştıkları en az ise \%14,5 ile "Fiziksel Sağlığı Hedef Almaya Yönelik Mobbing Davranışları Boyutu"na maruz kaldıkları ortaya çıkmıştır. Hemşirelerin olası mobbing davranışları içerisinde en çok "Yaptığınız iş sürekli eleştirilir." (\%43), "Kendinizi gösterme olanaklarınız kısıtlanır." ve "Meslektaşlarınız veya birlikte çalıştığınız kişiler kendinizi gösterme olanaklarınızı kısıtlar." $(\% 40,6)$ ve "Sözünüz sürekli kesilir." (\%40,3) ifadelerine; en az ise \%2,9'luk oran ile "cinsel saldırılar yapılır (taciz vb.)" 
ifadelerine maruz kaldıkları ortaya çıkmıştır. Benzer şekilde, Şahin ve Dündar'ın 2011 yılında sağlık çalışanları ile ilgili yaptıkları çalışmada da, olası mobbing boyutları içerisinde sağılık çalışanlarının en çok \%66,3 ile "iletişim Kurma Olanağını Hedef Almaya Yönelik Mobbing Davranışları"na maruz kaldıkları bulunmuştur (Şahin ve Dündar, 2011). Bunun yanı sıra Karsavuran'ın (2011) yııında yaptığı çalışmada da "iletişim Kurma Olanağını Hedef Almaya Yönelik Mobbing Davranışları"nın hastane yöneticilerinin en sık karşılaştıkları mobbing boyutu olduğu belirtilmiştir.

Fornés ve diğerleri tarafından İspanya'da hemşireler üzerine yapılan çalışmada da en sık karşılaşılan mobbing davranışları iletişim problemleri veya kişiler arası problemleri içeren iletişim sorunları olarak belirtilmiştir (Fornés ve diğ., 2011). "Sözünüz sürekli kesilir." ifadesi Şahin ve Dündar (2011), Karsavuran (2011) ve Dilman (2007) da yapılan çalışmalarda da en fazla maruz kalınan mobbing davranışı olarak bulunmuştur. Çalışmada belirtilen "cinsel saldırılar yapılır (taciz vb.)" ifadesi ise hem Şahin ve Dündar (2011) hem de Karsavuran (2011) tarafından yapılan çalışmalarda en az karşılaşılan mobbing davranışları olarak belirtilmiştir.

Sağlık alanında çalışan meslek gruplarının çeşitliliği, bu alanda ekip çalışmasının önemi, hasta ve yakınları ile iletişim halinde olma durumu gibi faktörler göz önüne alındığında "iletişim"in çalışanlar arasında yoğun olarak kullanıldığı söylenebilir. Çalışmada yöneticilerin en çok iletişim kurma olanağını hedef almaya yönelik davranışlara maruz kaldığı bulunmuştur. Bu durum çalışanlar arasında iletişim problemleri olduğunu göstermektedir. İletişim sorununa çözüm getirilmesi bu durumu ortadan kaldıracaktır.

Sağlık hizmetlerinin birden fazla sağlık profesyonelinin ortaklaşa çalışmasını gerekli kılan bir uğraş alanı olması, çalışanlar arasında yoğun bir iletişimi gerektirmektedir. İletişim kurma olanağını hedef almaya yönelik davranışların mobbinge maruz kalınan davranış olarak daha daha sık görülmesinin nedeni iletişimin yoğun yaşanması olarak açıklanabilir. Özellikle, karşılıklı görüşüp anlaşarak etkili kararların alınmasını sağlayan hastane yöneticileri için, iletişime yönelik yapılan saldırılar büyük bir tehdit unsuru olabilmektedir.

Çalışmada, hemşirelerin yöneticileri tarafından mobbinge maruz kalma durumları çalıştıkları hastane türüne göre incelendiğinde, istatistiksel olarak anlamlı bir fark olmamasına rağmen, hastane türü göz önüne alındığında en fazla mobbinge maruz kalanların devlet hastanesinde çalışan hemşireler olduğu ortaya çıkmıştır. Bunu sırasıyla üniversite hastanesinde ve özel hastanede görev alan hemşirelerin izlediği belirlenmiştir. Şahin ve Dündar (2011) tarafından sağlık çalışanları üzerine yapılan çalışmada ise "itibarı ve saygınlığı" ve "mesleki durumu" hedef almaya yönelik mobbing davranışlarına tıp fakültesi hastanesinde çalışanların daha fazla maruz kaldığı, "fiziksel sağlı̆̆ı" hedef almaya yönelik mobbing davranışlarına ise en çok özel hastanelerde çalışanların maruz kaldığı belirtilmiştir (Şahin ve Dündar, 2011). Şahin ve diğerlerinin asistan doktorlar üzerine yaptıkları araştırmada, üniversite veya özel hastanelerde çalışan doktorlarda mobbingin daha sık görüldüğü bulunmuştur (Şahin ve diğ., 2012). Yıldırım ve Yıldırım (2007) tarafından yapılan çalışmada; özel hastanelerde çalışan hemşirelerin devlet hastanesinde çalışan hemşirelerden istatistiksel olarak daha anlamlı şekilde daha fazla mobbing davranışlarına maruz kaldığı ortaya çıkmıştır (Yıldırım ve Yıldırım, 2007). 
Çalışmada hemşirelerin yöneticileri tarafından eğitim düzeylerine göre mobbinge maruz kalma durumları incelendiğinde, istatistiksel olarak anlamlı bir fark olmamasına rağmen, eğitim düzeyleri göz önüne alındığında en fazla mobbinge maruz kalanların sırasıyla yüksek lisans \& doktora eğitimi almış hemşireler, lisans mezunu hemşireler ile lise ve ön lisans eğitimi almış hemşireler olduğu belirlenmiştir. Bu çalışmanın aksine, Karsavuran (2011) tarafından yapılan çalışmada yöneticilerin eğitim durumlarına göre mobbinge maruz kalma düzeyleri arasında farklılık olduğu bulunmuştur. Farklılık bulunan tüm mobbing davranışlarında sağlık meslek lisesi ve ön lisans mezunlarının en fazla mobbinge maruz kalan grup olduğu bulunmuştur. Benzer biçimde Dilman (2007) tarafından hemşireler üzerine yapılan çalışmada da sağlık meslek lisesi mezunlarının yıldırmaya daha fazla maruz kaldığı belirtilmiştir. Kısa (2008) tarafından yapılan çalışmada da hemşirelerin eğitim durumları ile sözel taciz deneyimleri arasında bir ilişki olduğu bulunmuştur. Mesleki okul derecesine sahip olan hemşireler daha fazla sözlü tacize maruz kalırken, ön lisans mezunları, lisans mezunları ve lisansüstü derecesine sahip olanlar daha az sözlü tacize maruz kalmaktadır. Hemşirelerin eğitim seviyesi arttıkça sözlü tacize maruz kalma oranı azalmaktadır (Kısa, 2008)

Hemşirelerin yöneticileri tarafından kurumda çalışma şekillerine göre mobbinge maruz kalma durumları incelendiğinde, istatistiksel olarak anlamlı bir fark olmamasına rağmen, genel mobbing durumuna bakıldığında kurumda çalışma şekillerine göre en fazla mobbinge maruz kalanlar nöbet tutanlar, gündüz çalışanlar ve vardiyalı çalışanlardır.

Camerino ve diğerleri tarafından hemşireler üzerine yapılan çalışmada vardiyalı çalışan hemşirelerin (gece ve gündüz vardiyası veya sadece gece vardiyası) şiddet eylemlerine daha sık maruz kaldığı, tam zamanlı haftada 35 saat ve fazla çalışan hemşirelerin de üstleri ve arkadaşları tarafından sık sık tacize maruz kaldığı belirtilmiştir (Camerino ve diğ. 2008). Kısa (2008)'nın yapmış olduğu çalışmada ise hemşirelerin çalışma zamanları (vardiya) ile sözlü tacize maruz kalma durumları arasında anlamlı bir ilişki olduğu bulunmuş, gündüz çalışanların akşam ve gece çalışanlara göre daha fazla sözlü tacize maruz kaldığı belirlenmiştir (Kısa, 2008).

Çalışmada hemşirelerin yöneticileri tarafından çalıştığı bölüme göre mobbinge maruz kalma durumları incelendiğinde; "iletişim kurma olanağı", "itibar ve saygınlı̆ıı" hedef almaya yönelik mobbing davranışları ile "genel mobbing durumlarının" bölümlere göre istatistiksel olarak anlamlı bir farklııı gösterdiği bulunmuştur. Hemşirelerin hastanede çalıştıkları bölümlere göre yöneticileri tarafından mobbinge maruz kalma durumları en çok acil servis bölümünde meydana gelmekte ve bunu sırasıyla ameliyathane, yoğun bakım ve servis/poliklinik/müdürlük bölümleri izlemektedir. Benzer çalışmalara bakıldığında; Efe ve Ayaz tarafından 2010 yılında hemşireler üzerine yapılan çalışmada; yirmi beş yaş altındaki ve yoğun bakım ünitelerinde çalışan hemşirelerin diğer hemşirelere göre daha fazla mobbinge maruz kaldığı ortaya çıkmıştır (Efe ve Ayaz, 2010). Camerino ve diğerleri tarafından yapılan çalışmada hemşirelerin psikiyatrik, acil ve geriatrik servislerde ve uzun dönem bakımda, hasta ve yakınları tarafından şiddete maruz kalma oranı çok fazladır. Hemşirelerin geriatrik ve tıbbi / cerrahi servislerinde, uzun dönem bakım ve yoğun bakım ünitelerinde, üstleri ve meslektaşları tarafından tacize uğrama sıklığı biraz daha fazladır (Camerino ve diğ.,2008). Benzer şekilde Kısa (2008)'nın hemşireler üzerine yapmış olduğu çalışmada da en fazla sözlü tacize maruz 
Illkay Sevinç TURAÇ | Bayram ŞAHIN

kalanların yatan hasta ünitelerinde $\% 55,4$ çalışan hemşireler olduğu, bunu sırasıyla özel birimlerin (yoğun bakım üniteleri, acil servis) izlediği bulunmuştur (Kısa, 2008).

Zampieron ve diğerleri tarafından hemşireler üzerine yapılan çalışmada ise saldırganlığın acil servis, geriatri ve psikiyatri bölümlerinde ve kadın hemşirelerde daha sık yaşandığı belirtilmiştir (Zampieron ve diğ., 2010). Dilman tarafından yapılan çalışmada çalışılan bölüme göre duygusal tacize maruz kalma durumu istatistiksel olarak anlamlı bulunmuş, özelleşmiş birimlerde çalışan hemşirelerin \% 46,3 oranında duygusal tacize maruz kaldıkları tespit edilmiştir (Dilman, 2007).

Çalışmada hemşirelerin yöneticileri tarafından toplam çalışma yıllarına göre mobbinge maruz kalma durumları incelendiğinde; "mesleki durumu" hedef almaya yönelik mobbing davranışları boyutunun toplam çalışma yıllarına göre istatistiksel olarak anlamlı bir farklılık gösterdiği bulunmuştur. Toplam çalışma yılına göre mobbinge maruz kalanların \%35,5'i 5-10 yıl arası çalışanlardır. Bunu \%32,4 ile 5 yıldan az sürede çalışanlar ve \%23,2 ile 10 yıldan fazla sürede çalışanlar izlemektedir.

Çalışmada hemşirelerin yöneticileri tarafından yönetsel pozisyonlarına göre mobbinge maruz kalma durumları incelendiğinde; "itibarı ve saygınlığı" ve "mesleki durumu" hedef almaya yönelik mobbing davranışları boyutları ile yönetsel pozisyonları arasında istatistiksel olarak anlamlı bir ilişki olduğu bulunmuştur. Yöneticileri tarafından mobbinge maruz kalan hemşireler arasında "itibarı ve saygınlığı hedef almaya yönelik mobbing davranışları" boyutunda yöneticileri tarafından mobbinge maruz kalanların \%46,0'sının yönetsel pozisyona sahip olmayan hemşireler olduğu bulunmuştur. "Mesleki durumu hedef almaya yönelik mobbing davranışları" boyutunda ise yöneticileri tarafından mobbinge maruz kalanların \%31,1'inin yönetsel pozisyona sahip olmayan hemşireler olduğu bulunmuştur.

Çalışmada araştırmaya katılan hemşirelerin yöneticileri tarafından son 6 ay içerisinde 5 boyut altında sınıflandırılmış olası mobbing davranışlarından en az birine maruz kalma oranı \%68,5 olarak bulunmuştur. Benzer şekilde, Efe ve Ayaz tarafından 2010 yılında yapılan çalışmada mobbinge maruz kaldığını ifade eden hemşirelerin \%25,2'si mobbingi uygulayanın başhemşire olduğunu bildirmiş̧ir (Efe ve Ayaz, 2010). Bilgel ve diğerleri tarafından sağlık, eğitim ve güvenlik sektörlerinde yapılan çalışmada, zorbalığın çoğunlukla amir/yönetici gibi üst çalışanlar tarafından yapıldığı belirtilmiştir (Bilgel ve diğ., 2006). Şahin ve Dündar'ın (2011) sağlık çalışanları üzerine yaptıkları çalışmada da çalışanların en çok yöneticileri tarafından mobbinge maruz bırakıldıkları \%39,2 bulunmuştur (Şahin ve Dündar, 2011).

Yöneticiler tarafından olduğu kadar hasta ve hasta yakınları tarafından da mobbinge maruz kaIınabilmektedir. Erdemir ve diğerleri tarafından hemşireler üzerine yapılan çalışmada hemşirelerin \% 71,7'si hastaları tarafından cinsel tacize uğradıklarını belirtmişlerdir (Erdemir ve diğ., 2011). Zampieron ve diğerleri tarafından hemşireler üzerine yapılan çalışmada ise saldırganların genelde hasta ve hasta yakınları olduğu \%57 ve saldırgan davranışların çoğunlukla erkekler tarafından \%66 yapıldığı belirtilmiş̧ir (Zampieron ve diğ., 2010). 
Literatür incelendiğinde yöneticiler ve hasta/hasta yakınlarının yanı sıra meslektaşlar tarafından da mobbing davranışlarının yapıldığı görülmektedir. Çelik ve diğerleri tarafından hemşireler üzerine yapılan çalışmada hemşirelerin \%80'den fazlasının meslektaşları tarafından sözlü tacize maruz kaldığı bulunmuştur (Çelik vd., 2007). Rutherford ve Rissel tarafından bir sağlık kuruluşunda yapılan çalışmada işyeri zorbalığının nedeni olarak en fazla \%49 ile çalışma arkadaşları/meslektaşlar, \%42 ile müşteriler/hastalar ve \%38 ile yöneticiler veya süpervizörler bildirilmiştir (Rutherford ve Rissel, 2004).

Çamcı ve Kutlu tarafından bir sağlık alanında yapılan çalışmada şiddete maruz kalan sağlık çalışanlarına hangi tür şiddete kim tarafından maruz kaldıkları sorulduğunda; fiziksel şiddete maruz kalanların \%11,2'sinin hasta, \%9,7'sinin hasta yakını tarafından; sözel şiddete maruz kalanların \%89,9'unun hasta yakını tarafından; zorbalık/psikolojik tacize maruz kalanların \%17,9'unun yönetici tarafından; cinsel tacize maruz kalanların \%3,1'inin hasta tarafından şiddete uğradığı belirtilmiştir (Çamcı ve Kutlu, 2011). Samir ve diğerleri tarafından yapılan çalışmada da hemşirelerin en fazla $\% 38,5$ ile hasta yakınları tarafından, daha sonra ise \%29,3 ile bölümdeki yöneticiler tarafından şiddete maruz kaldığı belirtilmiştir (Samir ve diğ., 2012). Camerino ve diğerleri tarafından Belçika, Almanya, Finlandiya, Fransa, İtalya, Hollanda, Polonya ve Slovakya dahil olmak üzere sekiz AB ülkesinde hemşireler üzerine yapılan çalışmada, genel olarak, Avrupa örnekleminde, aylık, haftalık ve günlük olarak hasta ve hasta yakınlarından sonra en fazla üstleri tarafından hemşirelerin tacize uğradığı belirtilmiştir (Camerino vd., 2008).

\section{5. Öneriler}

Çalışmada hemşirelerin yöneticileri tarafından mobbinge maruz kaldığı belirtilmiştir. Yöneticilerden kaynaklanan mobbing davranışlarının önlenebilmesi için, yöneticilerin çalışanlar tarafından gelen şikayetleri dikkate alması, çalışanların görev ve sorumluluklarını iyi bilmesi ve uygulaması gerekmekle birlikte, iletişim sorunlarının çözülerek insan odaklı bir yönetim benimsenmelidir.

Çalışmada hemşirelerin en fazla mobbing davranışlarına acil servislerde maruz kaldıkları bulunmuştur. Acil servisler doğası gereği hızlı çalışmayı, dikkati ve işbirliğini gerektiren, hızı karar verilmesi ve dikkat edilmesi gereken bölümlerdir. Bu bağlamda acil servislerde çalışan hemşirelerin çalışma saatlerinin iyileştirilmesi, vardiya değişiminin sık olması bu davranışların azalmasını sağlayabilecektir.

Dahası çalışanların görev tanımları yapılmalıdır. Sürekli iletişim halinde olma durumu dolayısıyla "iletişim boyutunda" mobbing davranışlarının daha fazla olması ilgili sorunların bir an önce çözülmesi ve bu boyuttaki mobbing davranışlarını en az seviyeye indirgeyerek iyi bir iletişim ağı oluşturulması sağlanmalıdır. Mobbing ile ilgili bilgilendirmeler yapılmalı, mobbing davranışlarını önleyici politikalar hazırlanmalı ve bu konuyla ilgili etkili yasal düzenlemeler yapılmalıdır. Mobbing davranışlarını önleme ilgili eğitimler verilmeli, yöneticilerin ve çalışanların mobbing davranışları hakkında eğitim almaları ve bilinçlenmeleri sağlanmalıdır. Mağdurların mobbing davranışlarını yetkililere bildirmesi hem mobbing davranışlarını azaltabilecek hem de olası mobbing durumlarını engelleyebilecektir. 
Illkay Sevinç TURAÇ | Bayram ŞAHIN

Kaynaklar

Alpar, R. (2012). Spor, Sağlık Ve Eğitim Bilimlerinden Örneklerle Uygulamalı Istatistik Ve GeçerlikGüvenirlik. Detay Yayınclık

Bilgel, N., Aytaç, S. ve Bayram, N. (2006). Bullying in Turkish white-collar workers, Occupational Medicine, 2006; 56, s.226-231

Bolışık, B., Ak, B. ve Karabudak, S.S. (2008). Pediatri Hemşireliğinde Sık Karşılaşılan Bir Sorun: Sözel İstismar. Ege Pediatri Bülteni, 15 (2) s.76-78

Camerino, D., Estryn-Behar, M., Conway, P.M., Der Heijden, B., Hasselhorn, H. (2008). WorkRelated Factors And Violence Among Nursing Staff In The European Next Study: A Longitudinal Cohort Study, International Journal of Nursing Studies 45, s.37-47

Çamcı, O. ve Kutlu, Y. (2011). Kocaeli'nde Sağlık Çalışanlarına Yönelik İşyeri Şiddetinin Belirlenmesi, Psikiyatri Hemşireliği Dergisi - Journal Of Psychiatric Nursing 2(1), s.9-16

Çelik, S.Ş., Çelik, Y., Ağırbaş, i., Uğurluoğlu, Ö. (2007). Verbal And Physical Abuse Against Nurses İn Turkey, International Council of Nurses, s. 361-364

Çelik, Y. ve Çelik, S. Ş. (2007). Sexual Harassment Against Nurses in Turkey. Journal of Nursing Scholarship, s. 201-203.

Çobanoğlu, Ş. (2005). Mobbing, İ̧ Yerinde Duygusal Saldırı ve Mücadele Yöntemleri. Timaş Yayınları, İstanbul, s. 20.

Davenport, N., Distler-Schwartz, R. ve Pursell-Elliott, G. (2003). Mobbing, İsyerinde Duygusal Taciz. (O. C. Önertoy, Çev.). İstanbul: Sistem Yayıncılık

Dikmetaş, E., Top, M. ve Ergin, G. (2011). Asistan Hekimlerin Tükenmişlik ve Mobbing Düzeylerinin İncelenmesi. Türk Psikiyatri Dergisi, 22 s. 5-10

Dilman, T. (2007). Özel Hastanelerde Çalışan Hemşirelerin Duygusal Tacize Maruz Kalma Durumlarının Belirlenmesi, Yüksek Lisans Tezi, Marmara Üniversitesi, İstanbul, s. 160-165

Efe, S.Y. ve Ayaz, S. (2010). Mobbing against nurses in the workplace in Turkey. International Nursing Review, s. 329-331.

Erdemir, F., Çıtak, E. A., Ulusoy, H., Geçkil, E. (2011). Hemşirelerin Hastalar Tarafından Cinsel Tacize Uğrama Durumlarının Belirlenmesi, Sağlık Bilimleri Fakültesi Hemşirelik Dergisi (2011), s. 2935.

Ergun-Özler, D. ve Mercan, N. (2009). Yönetsel ve Örgütsel Açıdan Psikolojik Terör. Detay Yayıncılık, Ankara, s. 150

Fornés, J., Cardoso, M., Castelló, J. M., Gili, M. (2011). Psychological Harassment in the Nursing Workplace: An Observational Study, Archives of Psychiatric Nursing. Vol. 25, No. 3, s. 187-192 
Karsavuran, S. (2011). Ankara'daki Sağlık Bakanlığı Hastaneleri Yöneticilerinin Yıldırmaya Maruz Kalmalarıyla Tükenmişlik Düzeyleri Arasındaki İlişki. Yüksek Lisans Tezi. Hacettepe Üniversitesi, Ankara.

Kısa, S. (2008). Turkish Nurses' Experiences Of Verbal Abuse At Work, Archives of Psychiatric Nursing. Vol. 22, No. 4, s. 202-206

Leymann, H. (1990). “Mobbing and Psychological Terror at Workplaces" Violence and Victims Vol. 5 (2), s.120, Oxford Advanced Learner's Dictionary.

Quine, L. (2001). Workplace Bullying in Nurses. Journal of Health Psychology Vol 6(1), s. 76-80.

Quine, L. (1999). Workplace bullying in NHS community trust: staff questionnaire survey. BMJ Volume 31823 January. www.bmj.com, s.320-325

Rutherford, A., Rissel, C. (2004). A Survey Of Workplace Bullying In A Health Sector Organisation, Australian Health Review Vol 28 No 1, s. 67-71

Samir, N., Mohamed, R., Moustafa, E., Saif, H. A. (2012). Nurses' Attitudes And Reactions To Workplace Violence İn Obstetrics And Gynaecology Departments in Cairo Hospitals, Eastern Mediterranean Health Journal EMHJ Vol. 18 No. 3, s. 200-201

Şahin, B. ve Dündar, T. (2011). Sağlık Çalışanlarının Yıldırma (Mobbing) Davranışlarıyla Karşılaşma Düzeylerini Etkileyen Faktörlerin İncelenmesi: Bolu ỉli Örneği, Tisk Akademi cilt:2 (12), s.103104.

Şahin, B., Çetin, M., Çimen, M., Yıldıran, N. (2012). Assessment of Turkish Junior Male Physicians' Exposure to Mobbing Behaviour: Croat Med J. CMJ;53, s.357-366.

Tekeş, B., Turhan, N. A., Keskin, S., Sur, Ö., Kızıltaş, F. (2011). Fiziksel Ve Psikolojik Şiddetin Meslek Gruplarına Göre Dağılımı Araştırması, 11. Uluslararası Sağlıkta Performans ve Kalite Kongresi Poster Bildiriler Kitabı Ankara

Tınaz, P. (2011). İsyerinde Psikolojik Taciz (Mobbing). İstanbul: Beta Yayınları. 6-10

Toker-Gökçe, A. (2008). Mobbing: İ̧̧yerinde Yıldırma Nedenleri ve Başa Çıkma Yöntemleri. Pegem Yayınları, Ankara 4-63

Yaman, E. (2009). Yönetim Psikolojisi Açısından Iş̧yerinde Psikoşiddet -Mobbing-. Nobel Yayınları, Ankara 10-14

Yıldırım, A. ve Yıldırım, D. (2007). Mobbing in the Workplace by Peers and Managers: Mobbing Experienced by Nurses Working in Healthcare Facilities in Turkey and its Effect on Nurses: Journal of Clinical Nursing, s.1446-1450

Yıldırım D. ve Yıldırım, A. (2008). Development and Psychometric Evaluation of Workplace Psychologically Violent Behaviours Instrument. Journal of Clinical Nursing. 1363-1367 


\section{Illkay Sevinç TURAÇ | Bayram ŞAHIN}

Yıldırım, D. (2009). Bullying Among Nurses and its Effect:International Nursing Review, 506-508.

Zampieron, A., Galeazzo, M., Turra, S., Buja,A. (2010). Perceived Aggression Towards Nurses: Study İn Two Italian Health Institutions, Journal of Clinical Nursing, 19, 2329-2341, http://www.who.int/mediacentre/news/releases/release37/en/ 29/08/2013 tarihinde erişim sağlandı. 